\title{
MISSA DOS QUILOMBOS: um canto de Axé
}

\author{
Selma Suely Teixeira \\ Mestre em Literatura Brasileira, pela UFPR
}

\begin{abstract}
"Em nome de um deus supostamente branco e colonizador, que nações cristãs têm adorado como se fosse o Deus e o Pai de Nosso Senhor Jesus Cristo, milhões de negros vêm sendo submetidos, durante séculos, à escravidão, ao desespero e à morte. No Brasil, na América, na África mãe, no Mundo."

D. Pedro Casaldáliga

Arcebispo de São Félix do Araguaia
\end{abstract}

A de Ó (Estamos chegando)

No conjunto de fatores da formação étnico-cultural brasileira, a contribuição negra foi, até recentemente, a mais esquecida.

O prestígio singular da raça branca à qual devemos os nossos padrões, foi imperialista $\mathrm{e}$ absorvente, pois o monopólio branco dos meios de produção da terra brasileira e de sua direção política e econômica, reflete-se no direcionamento da formação cultural do país.

A época dos descobrimentos, alimentada pelos princípios expansionistas do Século das Luzes, e a "missão" de conversão dos pagãos incorporada por Portugal, trouxe os portugueses para o Brasil.

Por volta de 1521, D. João III, rei de Portugal escreve a Tomé de Souza, primeiro governadorgeral do Brasil, sobre a principal causa do povoamento do Brasil: "a conversão da gente do Brasil à Santa Fé Católica." Tendo recebido do papa o direito de padroado, o rei português iniciava uma estreita aliança entre a Igreja e o Estado.

Ante a necessidade premente de povoação e colonização das novas terras, a Coroa Portuguesa inicia o projeto das capitanias hereditárias que têm como missão inicial guardar o território brasileiro. Mas era necessário, também, implantar um sistema de produção que viesse fornecer rendimentos a Portugal.

A queda na produção de açúcar na Sicília, mostrou o caminho a ser tomado. As terras férteis e abundantes poderiam, desde que cultivadas, suprir o mercado europeu proporcionando grande riqueza à Coroa. O único problema era a mão-de-obra que deveria ser utilizada em grande quantidade.

Não podendo conseguir trabalhadores livres, pois o povo português não via incentivos para emigrar para a colônia, a produção foi organizada em torno do trabalho escravo.

Com a recusa do indígena a este tipo de relação, iniciou-se a importação da mão-de-obra da África que consolidou a expansão açucareira. E para que houvesse um consenso geral sobre a escravidão, o governo português recorreu à Igreja para que desenvolvesse uma teologia 
justificativa da escravidão.

É criada, então, a teologia da transmigração, em que a África é comparada ao inferno, onde o negro era o escravo de corpo e alma; o Brasil, é o purgatório, onde o negro era liberto na alma pelo batismo; e a morte, a entrada no céu.

Em um sermão do padre Vieira aos "irmãos" de uma Irmandade do Rosário dos Pretos no Recôncavo Baiano, em 1633, pode-se constatar o discurso do poder eclesial: "Quando servis aos vossos senhores, não os sirvais como quem serve a homens, senão como quem serve a Deus, porque então não servis como cativos senão como livres, nem obedeceis como escravos, senão como filhos."

Diante dos africanos, a ação da Igreja nunca foi concebida em termos de missão, como indicava a causa primeira da colonização. Em oposição à catequese dos índios, a dos negros foi desde 0 início realizada em português, numa contribuição ao desenraizamento do povo africano.

Os próprios jesuítas, assim como outras ordens religiosas, viviam do trabalho dos negros, tanto nos colégios como nos aldeamentos. Segundo mostra um relatório de 1870, dentre os bens dos beneditinos consta que estavam 1.265 escravos. Já os carmelitas possuíam 1.050 e os franciscanos 40 escravos. As religiosas possuíam 405 escravas e servas. Eram os escravos "dos santos".

Num relato do índio Momboré-uaçu aos colonizadores franceses do Maranhão, em 1612, podese perceber o relacionamento entre evangelização e escravidão: "os portugueses mandaram vir os padres e mais tarde afirmaram que nem eles nem os padres podiam viver sem escravos para os servirem e por eles trabalharem."

O batismo, através de um decreto assinado pelo papa Gregório XIII, em 1585, fazia parte das formalidades do tráfico negreiro. Era a imposição de um nome estranho e sem significado para o negro. Quanto ao casamento, não se hesitou em desfazer laços conjugais realizados na África, separando-se famílias inteiras. No contexto dos ciclos missionários, a escravidão era tolerada como um "mal necessário."

O escravo teve que lutar só, não encontrando na lgreja nem apoio, nem defesa.

Em 1850, apesar do Parlamento ter decidido terminar com a importação de escravos em 1831, permanecia a importação ilegal de negros, que tem como resultado a prosperidade da burguesia. A riqueza do Império, baseada nesse "caixa dois", chegou a movimentar quantias equivalentes a mais da metade do valor das exportações legais do país.

Em 1885, é promulgada a lei dos sexagenários, que tinha por objetivo amenizar o sistema escravagista contestado pelos defensores da formação de um estado nacional. A partir de então, a questão negra vai se tornando cada vez mais predominante, desembocando na questão da abolição, que não foi propriamente um divisor de águas na história do negro no Brasil, uma vez que motivada por fatores sócio-econômicos subjacentes no plano nacional e internacional, que faziam da escravatura uma instituição obsoleta na época.

Depois da Abolição, quando seria possível uma ascensão de negros e mulatos, começaram a surgir teorias científicas, aparentemente neutras, sobre a inferioridade racial negra.

A libertação era um presente, e uma concessão do proprietário branco, e ao preto só cabia 
demonstrar para sempre sua lealdade e gratidão.

Os ex-escravos, eternos "credores", davam origem às relações de clientelismo tão presentes em toda a República Velha.

Os critérios para a libertação, por sua vez, não eram aleatórios: quanto mais "próximo do espírito branco", mais perto da libertação e da cidadania.

Do ponto de vista do branco, escravo ou ex-escravo, o negro continuava a ser "coisa ou propriedade, um ser sem personalidade, sem corpo, sem antepassados, sem nome nem cognome, sem bens próprios. Um corpo sem persona, o próprio vazio social."(1)

Entre 1888-1900, os negros são fixados nas fazendas. Assimilados teoricamente como cidadãos, são vistos como portadores de um caráter degenerado e representados por suas práticas bárbaras: "os sambas, as capoeiras e as feitiçarias."

O negro é, ao mesmo tempo, "bruxeiro ou bárbaro, violento ou educável, dependente ou insubmisso, 'espécie bela' ou 'plena de vícios." (2)

Em novembro de 1889, com a Proclamação da República, os libertos confirmam com suas ações aquilo que a ciência "comprovava" - a "inferioridade" e os costumes "selvagens" herdados de seu continente e condição de origem. O negro é marcado pelo estigma do cativeiro e de sua origem.

No final da década de 1890, novas e velhas imagens sobre negros delineiam-se, revelando basicamente a sua incapacidade de conviver com os "avanços" que o novo momento político trazia.

Entre 1822 e 1831, Hegel desenvolve em Lições de Filosofia da História Universal, a idéia de que a África e a América eram continentes imaturos e impotentes, não lhe parecendo aptos a fazerem parte de seu conceito de História Universal.

Mundos de negros ou índios, seu destino era a condenação de vagar no estado natural, a menos que, através do contato com o europeu colonizador, fossem tocados pelo Espírito.

À América, sobretudo a latina e a indígena, ainda se colocava um futuro. À África, sequer era vislumbrada uma futuridade. Alegava o filósofo que sua barbárie, violência e selvageria nada podiam prover à civilização.

Invisível e inaudível, essa humanidade ficou "condenada na terra." Costumes desprezados em virtude de uma concepção simplificadora do progresso, "milhões de homens arrancados de seus deuses, de sua terra, de seus hábitos, de suas vidas, da vida, da dança e da sabedoria"(3), os africanos foram despojados de tudo, a não ser da vida física.

Em sua luta por uma continuidade e um espaço social próprio, encontraram na organização de instituições, a possibilidade de uma coesão grupal e uma singular identidade.

Operando como anticorpo aos projetos de dominação ideológica e cultural que se concretizavam na repressão aos hábitos e costumes africanos, o sistema cultural negro se manteve em permanente processo de transmissão, permanecendo até hoje expressões da memória nacional e corpórea dos africanos como o candomblé, o samba, a capoeira, os orixás, 
os cantos seriados, os rituais.

Através da permanência de seus folguedos, danças e batuques, os negros criaram uma descontinuidade cultual em face à ideologia do Ocidente.

Às marcas brancas da ignorância, superstição e sincretismo, o negro dá um sentido tático. "À ignorância, tática de esconderijo; à superstição, artimanha de tenacidade e resistência e ao sincretismo, um mecanismo de sobrevivência."(4)

Outra forma de organização negra é a dos quilombos, reduto dos negros fugitivos dos engenhos ou fazendas.

Em fins do século XVI, com a sublevação de escravos negros de um grande engenho de açúcar localizado na antiga capitania de Pernambuco, atual estado de Alagoas, tem início o maior de todos os quilombos: o de Palmares.

Formado por segmentos marginalizados pela sociedade escravista - índios, mulatos, mamelucos e até brancos vítimas da exploração - , Palmares chegou a ter 20 mil habitantes. A base de sua economia era a agricultura policultora: milho, feijão, batata-doce, banana e canade-açúcar.

Tendo por chefe maior Zumbi (deus negro da guerra), neto de Gamga Zumba, herói da maioria negra, Palmares resistiu a todas as expedições de 1630 a 1695 organizadas pelo governo colonial e pelos senhores de engenho, que viam no fortalecimento do quilombo uma ameaça para sua segurança político-econômica.

A religião praticada pelos quilombolas era o catolicismo porque se tratava já de uma religião consolidada, o que servia de elo de união entre negros de diversas proveniências africanas. Os santos católicos eram tão mais presentes que os orixás africanos, que no Quilombo dos Macacos, capital da República dos Palmares, foi descoberta em 1695, após a morte de Zumbi, uma capela com as imagens do Menino Jesus, Nossa Senhora da Conceição e São Brás, que tinham sido adoradas pelos quilombolas.

O catolicismo nos quilombos é alternativo do catolicismo nos engenhos, apresentando uma imagem menos usual de evangelização: a de resistência e tenacidade de um povo que conseguiu fugir dos engenhos e dos arraiais, e não mais a ideologia da expansão do sistema colonial capitalista.

Os quilombos, enquanto organizações religiosas, salvaram milhões de negros do desespero e da morte física ou moral, pois davam algum sentido aos vencidos enquanto mantenedores da preservação da esperança.

Mantendo viva a fé em seus deuses e nos deuses do colonizador, os vencidos transformaram o "Brasil na terra de Tupã, de Oxalá, dos mestres da Jurema e dos Babalorixás."(5) Na terra do "Deus de todos os nomes."

Esse sentido da esperança do "Deus conosco" não foi reconhecido pela lgreja colonial, comprometida com os intentos dos Estados colonizadores, ao ponto de o padre Antonio Vieira não permitir que os negros aquilombados em Palmares recebessem os sacramentos, pois "eles lá vivem em estado de pecado mortal e devem voltar aos engenhos para receberem os sacramentos."(6) 
Quando em 1955, Lévi-Strauss escreve Raça e História, a pedido da UNESCO, ele retira todo valor operatório do conceito de raça.

As diferenças existentes entre os grupos humanos se devem, escreve "a circunstâncias geográficas, históricas e sociológicas, e não a aptidões distintas ligadas à constituição anatômica ou fisiológica dos negros, dos amarelos ou dos brancos."(7)

No final do século XIX, a visão branca e dominadora que os senhores de escravos brasileiros tinham sobre a raça negra, reforçava sua posição de autoridade e prestígio.

Enquanto a África era interpretada como "berço do barbarismo, da violência, da superstição e da magia", a Europa representava a civilização, o progresso e a paz. E o senhor branco aparecia nos noticiários dos jornais sempre "como a vítima absoluta, como o indivíduo estimado, civilizado e conhecido, enquanto o negro aparecia sempre como 'culpado da ação', bárbaro, traiçoeiro, violento e 'desconhecido'". (8)

Segundo as teorias científicas da época, "a cor morena era prova de desequilíbrio e de pouca civilidade."(9) A própria palavra negro já trazia em si, fatos infames, violentos e reprováveis e expressões como "negro crime" eram utilizadas com freqüência para caracterizar fatos violentos.

Quase que simultaneamente à abolição da escravatura, ocorreu a Proclamação da República, e com ela o negro passou a ser visto como o principal entrave para fazer do Brasil um país europeu.

Uma primeira tentativa para "solucionar" o problema, é dada por Rui Barbosa, "que manda queimar todos os arquivos sobre a escravidão no Brasil, propondo a amnésia sobre nossa origem como ideologia nacional."(10)

Reforçando as alegadas diferenças entre negros e brancos, surgem no começo do século as teorias arianistas adotadas por Nina Rodrigues, que hierarquizava os diversos povos, procurando demonstrar que a idéia de igualdade entre negros e brancos era mera utopia. Sílvio Romero, por sua vez, culpava a miscigenação como causa de nossa inferioridade como povo.

Em 1933, Gilberto Freyre cria em seu Casa grande e Senzala, o mito da democracia racial brasileira, interpretando a história brasileira através do processo de miscigenação.

Para ele, as culturas negras da África juntamente com os "negros antropologicamente negros, passaram desde o século XVI a serem presenças marcantes, atuantes, influentes e contribuintes na formação do Brasil."(11)

Freyre via os negros como co-colonizadores do Brasil, pela sua contribuição para a emergência de novos tipos físicos de homens e mulheres, além das influências religiosas, lingüísticas, rítmicas e culinárias.

Com o sentido de abordar na história da civilização brasileira uma ordem distinta da vigente até então, tem início uma retificação da perspectiva de estudo da influência africana no Brasil em que se notabilizara Nina Rodrigues. No I Congresso Afro-Brasileiro realizado em 1934, no Teatro Santa Isabel, no Recife, começa-se a reconhecer "cultos como a umbanda, como liberdade religiosa de interesse para o relacionamento cultural Brasil-África."(12)

Os povos da África que tinham interiorizado o olhar do colonizador no Terceiro Mundo, 
encontraram um recurso contra a alienação, na idéia que diz que as culturas são equivalentes e que cada uma se justifica no interior de seu próprio contexto.

A partir de 50, vários estudos de sociólogos como Florestan Fernandes e Fernando Henrique Cardoso, começaram a apontar o quadro de uma discriminação social velada, no Brasil.

O racismo brasileiro, escondido atrás da pobreza que envolve a população negra, tem como alvo um cidadão que não vive a plenitude de seus direitos, permanecendo os costumes da Casa grande e da Senzala.

Ainda em 50, começam a aparecer clubes voltados para as atividades do lazer e é criado o Teatro Experimental do Negro. A partir daí inúmeras entidades são organizadas em todo o Brasil, culminando com o surgimento em 1978, do Movimento Negro Unificado contra a Discriminação Racial, hoje Movimento Negro Unificado.

Representando uma reação a critérios atemporais de Bem, Verdadeiro e Belo impostos por um erro secular, os negros voltam a se unir como no tempo dos quilombos, para exigir o reencaminhamento do Bem, do Verdadeiro e do Belo, às suas origens, para reconduzi-las ao pedaço de terra onde nasceram.

Assim, pela redescoberta e confirmação de sua cultura, a nação africana pode redefinir o seu direito à pluralidade e a uma identidade coletiva.

Em 1980, o Censo Demográfico analisou a situação do negro brasileiro pela primeira vez, e as estatísticas mostraram um retrato deprimente em matéria de desigualdade. Enquanto a população negra perfazia 44\% da população do país, portanto a minoria, pelo ângulo da pobreza a situação se invertia, pois se para cada dez brasileiros quatro eram negros, para cada dez pobres, seis eram negros.

E essa situação permanece, uma vez que a diferença de salários ganhos por um branco e por um negro sempre foi grande: "nos estados nordestinos, por exemplo, o trabalho do branco vale $50 \%$ mais que o do negro e em São Paulo, essa diferença sobe para 96\%."(13)

A 7 de janeiro de 1981, com o objetivo de reverenciar, cultuar e ampliar as próprias aspirações da alma nativa do negro, é inaugurado o Museu Afro-Brasileiro, da Universidade Federal da Bahia.

Funcionando como um esclarecimento da cultura negra à comunidade em geral, a montagem do Museu está dividida em três temas: "o fazer: realização utilitária de objetos como instrumentos musicais e técnicas de tecelagem e pintura; o crer: religioso, constituído de entidades, cultos dos mortos, dos ancestrais, dos vivos, das terras e das

bruxas e os processos aculturativos, mostrando através de fotografias, costumes, tipos e usos dos locais."(14) A África no Brasil e o Brasil na África.

Filiado ao Museu, está o Centro de Estudos Afro-Orientais que tem como proposta "subsidiar sem preconceitos, a compreensão de toda a problemática do País através de um de seus elementos formadores: o negro."(15)

As notícias mais recentes sobre organizações negras, são as de comunidades-terreiro que são em essência, "um sistema iniciático que transmite e elabora o conhecimento, a experiência 
individual e coletiva, de uma maneira específica, através de rituais, que reatualizam fatos históricos e experiências incorporadas à história dos terreiros."(16)

A Abolição, por não ser objeto de comemoração, não é absolutamente relembrada nesses terreiros. No dia da Abolição são invocados os "pretos velhos", o culto aos antepassados, aos escravos, aos negros africanos e crioulos. São homenageados não os patronos da abolição, mas os fundadores e transmissores da negritude.

Sendo o dia da Abolição um dia de significado ambíguo e enganoso, pois por trás da figura da Princesa Isabel estaria uma visão paternalista do branco, os movimentos negros propõem o dia 20 de novembro, dia da morte de Zumbi, como o Dia nacional da Consciência Negra, passando o dia 13 de maio a ser usado, num nível mais abstrato, "como a promoção do Brasil mulato."(17)

A recuperação da figura de Zumbi como o grande símbolo da raça negra é resultado direto da energia dos movimentos negros no Brasil.

A 20 de novembro de 1980 foi fundado na Serra da Barriga, em Alagoas, o Memorial Zumbi, que tem por objetivo fornecer apoio aos centros de documentação e pesquisa da história dos movimentos negros no Brasil, bem como aos centros de estudos afro-brasileiros.

Estiveram presentes à fundação do Memorial, os afoxés Malê, Orunmilá, llê Ayê e Badauê. Abdias do Nascimento também presente, fez um discurso onde invocou o poder e a força de Olorum, Xangô, Oxum e lansã para a concretização de um compromisso dos presentes em favor da luta dos negros.

Representando a ala progressista da lgreja, esteve D. Pedro Casaldáliga, Arcebispo da Prelazia de São Félix do Araguaia, que afirmou que "a presença da Igreja no local era como que um ato penitencial pela omissão com que se comportou secularmente frente ao problema do negro." Para ele, "a serra da Barriga significava a esperança de uma arrancada para uma nova consciência."(18)

Ara wara kosi mi fara (Todos unidos num mesmo Corpo, nada no mundo nos vencerá)

A 22 de novembro de 1981, D. Pedro voltava ao Recife para concelebrar com D. Hélder Câmara, Arcebispo de Olinda e Recife e D. José Maria Pires, Arcebispo de João Pessoa, a Missa dos Quilombos, composta por ele, Pedro Tierra e Milton Nascimento.

Na homilia, D. José Maria Pires (D. Pelé), denuncia o fato de que se "a lgreja da época houvesse marcado presença mais na Senzala do que na Casa Grande, mais nos Quilombos do que nas Cortes, outros teriam sido os rumos da História do Brasil nos seus primórdios, outra teria sido a contribuição do negro ao nosso desenvolvimento. Porque mesmo desenraizado do seu povo e sua terra, mesmo reduzido ao cativeiro e sujeito a jornadas de até 18 horas de trabalho conservou em si força de aglutinação e de preservação de seus valores originais. Estas forças foram principalmente a religião e a combatividade."

Incorporando estas forças, os Pedros uniram seu texto à "extraordinária beleza melódica, harmônica e rítmica"da partitura de Milton Nascimento, utilizando a estrutura da Missa para "inventariar o passado e fazer presente e futuro mais justos."

Anunciando "os sinais de uma nova aurora", a Missa dos Quilombos é uma celebração de liberdade, que narra "a Morte e a Ressurreição do Povo Negro na Morte e Ressurreição de 
Cristo", "nosso irmão que nasceu moreno da raça de Abrãao."(19) E tal qual a tradicional religião negro-africana que se apóia numa força suprema, vital, que os nagô denominam Axé, a Missa dos Quilombos explora forças da natureza e espíritos dos antepassados, que são cultuados pela comunidade negra, mostrando uma forte presença africana da religião no Brasil, em oposição à noção de um sincretismo religioso que tem por objetivo garantir a imagem de um país cristão, logo europeu.

No dizer do teólogo alemão Theodor Schnitzler, a missa, pelas suas divisões, desenrola-se como uma assembléia onde o presidente abre a sessão, saudando os presentes (na missa, Abertura: Em nome do Pai... e Saudação: O Senhor esteja convosco...). Após a saudação, o presidente da sessão procede à leitura da reunião anterior, fazendo um balanço das resoluções não cumpridas ( na missa, Reflexão sobre o passado: ato penitencial). Numa espécie de exposição de princípios, o dirigente exorta os presentes a uma fidelidade maior para com os objetivos da comunidade e em seguida anuncia o programa da reunião em curso (na missa, Declaração de princípios: Kyrie e Glória e a Oração). Começam então na assembléia, as deliberações, em cujo final o presidente se levanta e explica aos presentes o sentido das propostas submetendo-as à aprovação de todos (na missa, Primeira e Segunda Leituras e o Evangelho seguido da homilia). Por um ato deliberativo, as propostas são aprovadas e ratificadas, destinando-se expressamente a todos os membros da associação (na missa, Resolução: credo e Validade para todos: oração universal ou dos fiéis).

A Missa dos Quilombos, tal qual uma assembléia convocada para a celebração de um pacto, divide-se também em 10 partes: A de Ó (Estamos chegando), espécie de procissão de entrada, onde o negro conta a história de seus sofrimentos e a negação de sua raça; Em nome do Deus, onde de dentro do nome de Deus, o negro pede em nome do seu Povo à Santíssima Trindade; Rito Penitencial (Kyrie), onde o negro suplica pela sua dignidade usurpada; Aleluiá, onde o negro rejubila-se com a sua Ressurreição, anunciada pela palavra de Jesus; Ofertório, onde o negro traz seu corpo castigado e o produto do seu trabalho escravo para ser acolhido pelo Senhor; O Senhor é Santo, onde o negro dirige os apelos da comunidade a Cristo, o "Rei Salvador"; Rito da Paz, onde o negro faz um paralelo entre a Redenção de seu Povo e a Paz, comunhão de respeito e do trabalho sem escravidão; Comunhão, onde o negro comunga com seus irmãos um mesmo ideal de Libertação; Ladainha, onde o negro pede a intervenção da mulher humilde que gerou o Rei Salvador, pela causa de seu Povo e a Marcha Final (de banzo e esperança), onde o negro expõe o banzo, a esperança no novo Quilombo que virá.

Celebração pascal, a Missa dos Quilombos tem em seu texto, "um grito revoltado, triste e consciente contra a violência sofrida pelos negros em nosso país, ao longo da história e nos dias de hoje, e um canto de esperança, uma convocação à luta pela mudança."(20)

Em A de Ó, a procissão de entrada, o nós coletivo substitui o eu individual, evidenciando um empenho em delinear uma identidade (entidade) negra coletiva:

\author{
Estamos chegando do fundo da terra, \\ estamos chegando do ventre da noite, \\ da carne do açoite nós somos, \\ viemos lembrar.
}

Estamos chegando da morte nos mares, estamos chegando dos turvos porões, 
herdeiros do banzo nós somos, viemos chorar.

Estamos chegando dos pretos rosários, estamos chegando dos nossos terreiros, dos santos malditos nós somos, viemos rezar.

Estamos chegando do chão da oficina, estamos chegando do som e das formas, da arte negada que somos viemos criar.

Estamos chegando do fundo do medo, estamos chegando das surdas correntes, um longo lamento nós somos, viemos louvar.

(...)

Estamos chegando dos ricos fogões, estamos chegando dos pobres bordéis, da carne vendida nós somos, viemos amar."

E o negro assume sua própria fala, contando a história do seu ponto de vista:

"Do Exílio da vida, das Minas da Noite, da carne vendida, da Lei do açoite, do Banzo dos mares..."

Através da afirmação do que se veio fazer : "lembrar, chorar, rezar, criar, louvar, amar, dançar, cantar, gingar, cobrar, gritar, clamar, lutar ", ele convoca sua raça a valorizar sua memória e sua cultura e a lutar por elas, consolidando o processo de construção de uma consciência de ser negro na América.

As situações de tortura presentes até hoje na marginalidade do negro: "estamos chegando dos pobres bordéis(...), estamos chegando das novas favelas(...) Estamos chegando dos trens dos subúrbios,/ estamos chegando nos loucos pingentes,(...) estamos chegando dos tristes mocambos,(...) Estamos chegando do alto dos morros,/ estamos chegando da lei da Baixada,"bem como as de exibição da raça, "Estamos chegando dos grandes estádios, / estamos chegando da escola de samba, " ao invés de serem recalcadas e enriquecidas, surgem impregnadas de um novo vigor, levando o negro a acreditar em "novos Albores!"

Crença possível hoje, devido à ancestralidade da prática religiosa proveniente dos quilombos, 
onde o catolicismo imposto pelo branco foi transformado em lição de resistência e tenacidade de um povo que conseguiu fugir da escravidão portuguesa. E é "Em nome do Deus verdadeiro/ que amou-nos primeiro/ sem dividição", que o negro une a Santíssima Trindade

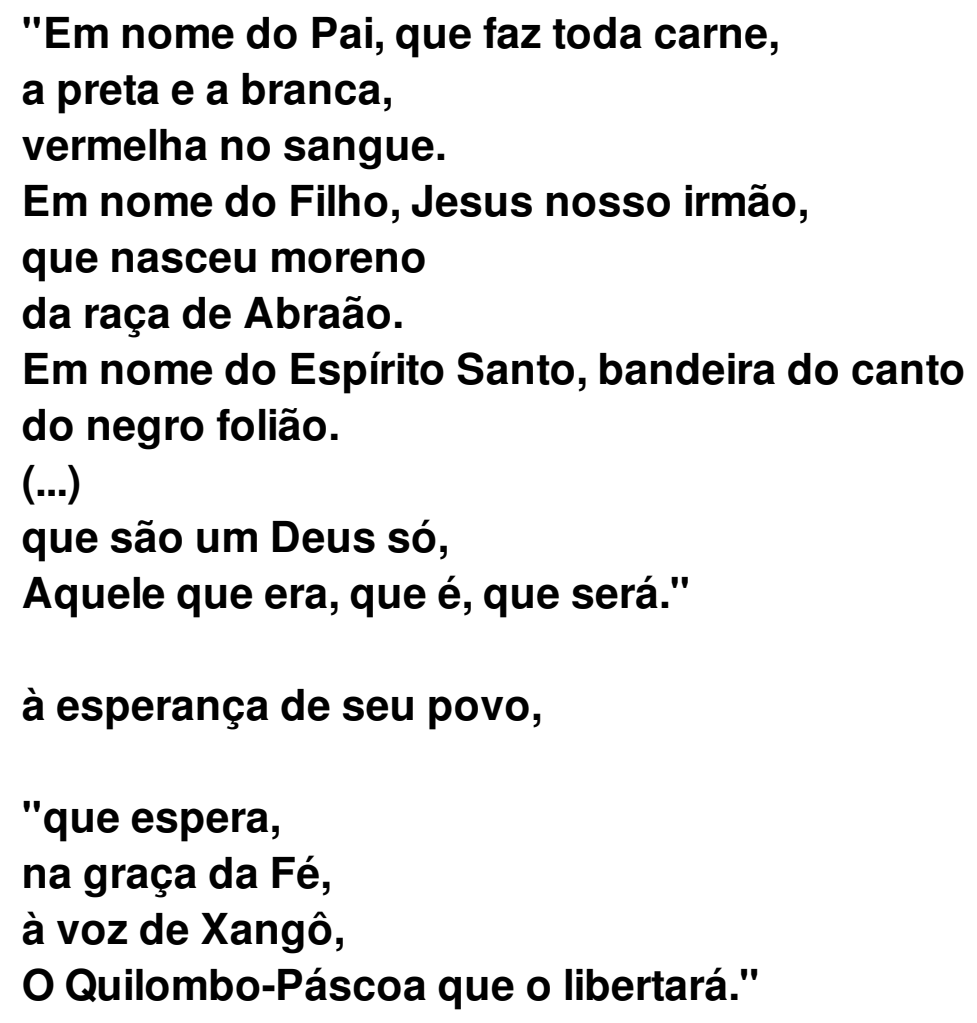

"Em nome do Pai, que faz toda carne, a preta e a branca, vermelha no sangue.

Em nome do Filho, Jesus nosso irmão, que nasceu moreno da raça de Abraão. Em nome do Espírito Santo, bandeira do canto do negro folião.

(...)

que são um Deus só, Aquele que era, que é, que será."

à esperança de seu povo,

"que espera, na graça da Fé, à voz de Xangô, O Quilombo-Páscoa que o libertará."

No Rito Penitencial da Missa dos Quilombos, os autores preferiram adotar aquela que é considerada a fórmula de oração do ato penitencial mais problemática e a mais anterior de todas: a que coloca o Kyrie dentro do ato penitencial.

Elaborado como um grito de lamentação de uma raça:

"Carne em toneladas, fardos de porão.

Quota da Coroa fichas de Batismo, marcados a ferro para a Salvação. Entregues à Morte, sendo Cristo a vida. Humanos leilões, peças de cobiça. 300 milhões de africanos mortos na Segregação."

Caça das Bandeiras, do Esquadrão da Morte.

Exus do destino, capitães-do-mato. Quantos Jorge Velho 


\section{de todos os Lucros, de todos os Tempos, de todas as Guardas! \\ Quantas Áureas leis \\ da Justiça Branca!"}

e não como uma confissão de faltas, o Rito Penitencial da Missa dos Quilombos comporta o Kyrie Eleison, autêntico grito de súplica, que exprime a confiança na justiça daquele que está sendo invocado. Canto comunitário, o Kyrie tem em suas origens a invocação mais fervorosa da antiga religiosidade pagã, adoradora do Sol, encaixando-se, portanto, numa celebração que denuncia "cultos condenados e fé de freguesia."

Sobre o número de invocações do Kyrie, os autores preferiram também retomar a determinação de Gregório Magno que definiu em nove o número de invocações, por considerar o aparecimento de Cristo cercado por um cortejo de nove coros de anjos, o que dá ao Kyrie um caráter de Sanctus antecipado.

No Rito Penitencial, os negros pedem pelo irmão que se deixou "embranquecer"para sobreviver, e conclamam, tal qual a volta de um filho pródigo, a reintegração do mulato à sua raça, para que não se envergonhando mais de si, possa encontrar sua liberdade:

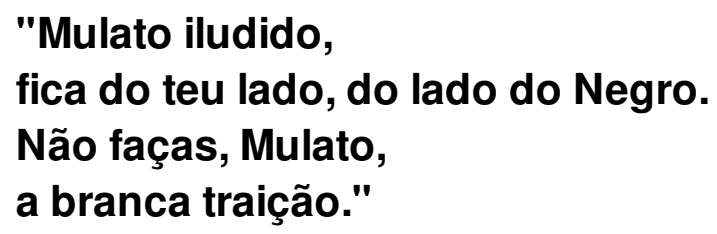

E em nome da Irmandade dos povos da "Pátria de Aruanda", pedem ao branco "Exus do destino", que não neguem
"o Sangue,
o grito dos Mortos, o cheiro do Negro, o aroma da Raça, a força do Povo, a voz de Aruanda, a volta dos QUILOMBOS!"

Em tempos de Páscoa, de Ressurreição, canta-se o Aleluia. Antecedendo a palavra de Deus que "fala a Verdade aos Irmãos" e traz a "nova de Libertação", a Missa dos Quilombos canta o júbilo a Jeová, aquele que "contra tantos mandatos do Ódio", traz "a Lei do Amor./ Frente a tanta Mentira", traz "a Verdade".

Fazendo do seu corpo e dos sofrimentos passados por ele os donativos maiores, o negro oferece juntamente com o vinho e o pão, "o mel do suor,(...) a dança da vida, (...) a Morte vencida, (...) os surdos lamentos,/ calados tormentos,(...) a força dos braços (...), os rosários de penas (...), o corpo domado (...)", para o sacrifício do Senhor, integrando "a luta e a fé dos irmãos", no "Corpo e Sangue de Cristo".

A "cabeça cortada / do Negro Zumbi,/ guerreiro do Povo,"/ é entregue como símbolo do "pranto 
dos negros", que tiveram a alma e o corpo lavrados em "caminhos de cruz", pela "brasa dos ferros".

A apresentação de alimentos e/ ou minérios cultivados para o uso e enriquecimento dos brancos

"- Com a força dos braços lavramos a terra

cortamos a cana, amarga doçura na mesa dos brancos.

-Com a força dos braços cavamos a terra, o negro café, perene alimento do lucro dos brancos.

-Com a força dos braços, o grito entre os dentes, a alma em pedaços, erguemos impérios, fizemos a América dos filhos dos brancos!"

e a apresentação dos alimentos e/ ou utensílios de uso pessoal:

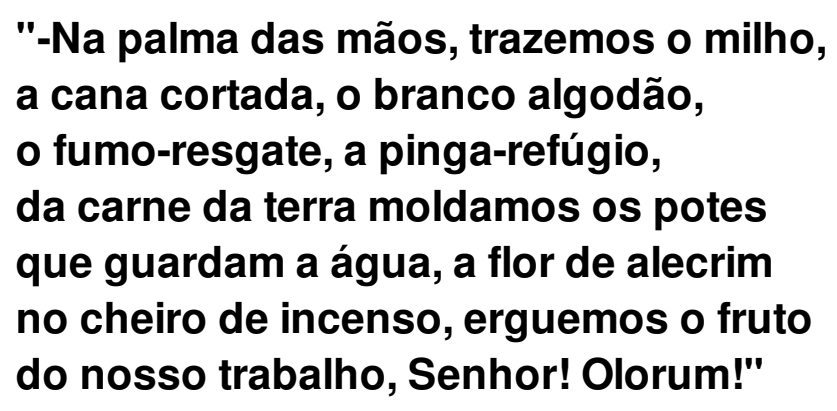

são feitas como depositárias de uma história que espera poder ensaiar "libertos, / a marcha do povo,/ a festa dos negros(...)"

O cântico do Sanctus (O Senhor é Santo, na Missa dos Quilombos) é, segundo a prescrição da Missa, um texto a ser dito pelo povo, dirigindo-se as orações da comunidade principalmente a Cristo, o Filho de Deus.

Em seu reconhecimento pelo Deus santo, Aquele que está acima de tudo ("O Senhor é o só Senhor,/ Todos nós somos iguais.") o negro pede aqui a ajuda do "Cristo Rei Salvador", para que o "Reino" se faça "no povo Libertador": "Hosana, Hosana, Hosana."

O Rito da Paz, que dá seqüência ao Sanctus, inicia com a saudação Àquele que tem a Paz:

"Saravá

A-i-é

Abá

A Paz d'Aquele que é nossa Paz!"

para que o recebimento dessa Paz, possa constituir a união e celebração da "Paz que o Povo fará!", quando vir concretizada
"A louca Esperança
de ver todo irmão
caindo na dança
da vida, cantando vencida 
"Contra a paz cedida" pelo falso humanitarismo dos defensores da Abolição, irá se opor a "Paz conquistada", não sendo portanto casual a indicação de a Lei Áurea ser cantada "à maneira de um Pregão", pequena melodia de ritmo livre, com a qual os vendedores anunciam suas mercadorias.

Cansados de serem considerados "carne em toneladas,/ fardos de porão", o povo negro parte para a conquista de seu espaço.

"Ara wara kosi mi fara": Todos unidos num mesmo corpo, não há nada no mundo que possa contra mim". Esse o grito de Comunhão da raça negra que celebra a Palavra de Deus dada através de seu Corpo e Sangue à comunidade participante.

\author{
"Bebendo a divina bebida \\ do teu Sangue Limpo, Senhor, \\ lavamos as marcas da vida, \\ libertos na Lei do Amor. \\ Comendo a carne vivente \\ do Teu Corpo morto na Cruz, \\ vencemos a Morte insolente \\ na vida mais forte, Jesus."
}

Na partilha do sacrifício, chega-se aqui ao centro de toda a celebração:

"- Partilha diária em mesa de irmãos.

Porque não é livre quem não tem seu pão.

-Partilha constante, na festa e na dor.

Porque não é livre quem não sente amor.

- Partilha fraterna de bantus iguais.

Porque não é livre quem junta de mais.

- Partilha de muitos unidos na fé

Porque não é livre quem não é o que é.

-Partilha arriscada de vir a perder.

Porque não é livre quem teme morrer."

O povo negro sente que na comunhão de idéias, interesses, afetos, lembranças e esperanças estão unidos num mesmo Corpo, identificando-se entre si enquanto raça e cultura.

Após terem estado "Unidos à procura dos quilombos da Libertação", celebrando "a "memória perigosa'da Páscoa de Jesus, comungando a força do seu Corpo Ressuscitado", recolhendo "na mesma comunhão o trabalho, as lutas, o martírio do Povo Negro de todos os tempos e de todos os lugares", a comunidade negra passa a invocar "sobre a caminhada, a presença amiga dos Santos, das Testemunhas, dos militantes, dos Artistas, e de todos os construtores anônimos da Esperança Negra." a Ladainha, oração formada por uma série de invocações curtas, que inicia com a convocação do rei Zumbi, "patriarca mártir de todos os Quilombos de ontem, de hoje e de amanhã." 
defensores da causa negra são convidados a participar de um novo tempo.

"Tempo de África, vida nova, mais justa e mais livre", quando será possível o tornar-se negro.

Após a invocação de "todos os mártires da Paz perseguida", é chegada a hora de se louvar a serva do Senhor, a que gerou o Libertador:

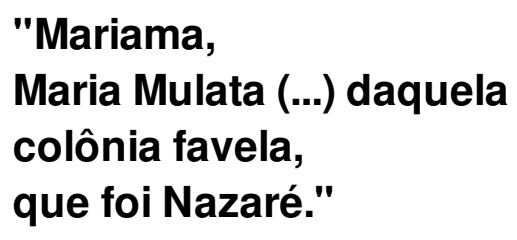

Escolhida por Deus para a realização de "duas divinas Missões: do Espírito e do Filho, pois foi através dela que se concretizou a humanização de Deus e a divinização dos homens"(21): "Por teu Ventre Livre, que é o Verdadeiro, pois nos gera livres no Libertador."

Revelada nas fontes de fé como mulher solidária com a paixão de seus irmãos "Fiel Companheira da Libertação", Maria que pede a Deus que dispense os soberanos, derrube do trono os poderosos, despache de mãos vazias os ricos em favor dos humildes, Maria é solicitada para erguer "os submetidos, acender os olhares,/ ajuntar os escravos em novos Palmares" e a descer novamente conforme a tradição popular, "às redes da vida, do teu Povo Negro,/ Negra Aparecida!!!"

Se se considerar a Missa como um memorial, é perfeitamente concebível a formulação de Banzo e de Esperança contida na Marcha Final da Missa dos Quilombos.

Enquanto sistema de resistência praticado através dos suicídios coletivos, sacrifícios de recémnascidos, assassinatos dos senhores, fugas isoladas e coletivas que culminaram nos quilombos, o Banzo foi interpretado pelo branco como demonstração de debilidade dos negros e não como expressão da vida comunitária e das relações do homem com o mundo e com Deus. Nesta Marcha Final, o negro proclama o Banzo como a saudade de uma pátria que poderá vir a ser:

\footnotetext{
"Banzo da Terra que será nossa, banzo de todos na Liberdade, banzo da vida que vai ser outra, banzo do Reino, maior saudade, saudade em luta do Amanhã, vontade da Aruanda que um dia virá!

(...)

Seremos o Povo dos Povos:

Povo resgatado, Povo aquilombado, livre dos senhores, de ninguém escravo, senhores de nós, irmãos de senhores, filhos do Senhor!"
} 
Numa terra de Tupã, de Oxalá, dos mestres da Jurema e dos babalorixás, o desejo de que cada povo possa ter sua consciência, encontrando-se em sua cultura:
"Sendo Negro o Negro, sendo índio o índio sendo cada um como nos tem feito a mão de Olorum."

Cativo de sua ascendência, herdeiro da tradição que o precede e ultrapassa sua reflexão, o negro encontra sua afirmação social e estética na compreensão de que pertence a uma unidade maior, de dimensão internacional:

\author{
"Os Negros da África, \\ os afros da América, \\ os Negros do Mundo, \\ na Aliança com todos os Pobres da
}

Terra."

E se proclama o "Povo dos Povos":
"Povo resgatado, Povo aquilombado, livre de senhores, de ninguém escravo, senhores de nós, irmãos de senhores, filhos do Senhor!"

É o nascimento de uma comunidade própria:

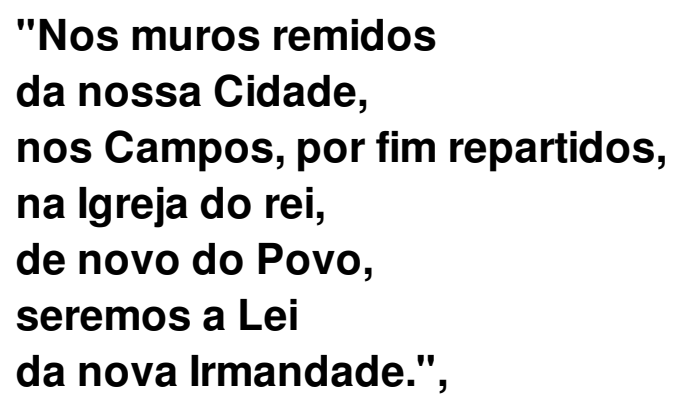

dentro de um espaço caloroso de uma fraternidade combatente:
"Pela Terra inteira juntos dançaremos nossa Capoeira.
Seremos bandeira, seremos foliões.
(...)
Os prantos, os gritos, unidos num canto 
de irmãos corações, na luta e na festa do ano inteiro."

Axé

Em 1947, o projeto da Declaração dos Direitos Humanos apresentava como primeiro artigo: "O indivíduo realiza sua personalidade pela cultura: o respeito pelas diferenças individuais acarreta, pois, um respeito pelas diferenças culturais."(22)

Certamente, a identidade cultural é o princípio vital que inspira as decisões, as condutas, os atos percebidos como os mais autênticos, e uma nação cuja "vocação primeira é aniquilar a individualidade de seus cidadãos, não pode gerar um Estado de fato."(23)

Conhecedores da necessidade de retornar à posse de si mesmos depois de serem "arrancados de seus deuses, de sua terra, de seus hábitos, de suas vidas, da vida, da dança, da sabedoria" (24), o povo negro luta pelo reencontro de sua cultura, como forma única de liberdade absoluta, de reencontro com o Axé.

É a hora de se transformar em cantor de sua comunidade, ampliando as próprias aspirações da alma nativa do negro.

\section{NOTAS DE REFERÊNCIA}

1. SCHWARCZ, Lilia Moritz. Retrato em branco e negro: jornais, escravos e cidadãos em São Paulo no final do século XIX. São Paulo: Companhia das Letras, 1987. p.161.

2. Idem, ibidem.

3. CÉSAIRE, Aimé. Discurso sobre o colonialismo: presença africana. 1955. p.19.

4. HOOARNET, Eduardo. A igreja no Brasil-colônia (1550-1800). São Paulo: Brasiliense, 1982 (Tudo é história, 45). p.27

5. Idem, ibidem.

6. Idem, p. 77.

7. LÉVI-STRAUSS, Claude. Raça e história. In: . Antropologia Estrutural. Paris: Plon, 1973. p.387.

8. SCHWARCZ, Lilia Moritz. op. cit. p. 121.

9. Idem, p. 209.

10. CARVALHO, José Jorge de. Mestiçagem e segregação. Brasília: Humanidades, 1988. p.35.

11. FREYRE, Gilberto. Aspectos da influência africana no Brasil. Brasília, Cultura, out. dez. 1976. p.7.

12. Idem, p.18.

13. LEITE, Paulo Moreira. Centenário de um mau século. São Paulo, Veja, 11 maio 1988. p.29.

14. SILVA, Jacira. A casa da cultura negra. Brasília, Cultura, out. dez. 1981. p.24.

15. Idem, ibidem.

16. SANTOS, Juana Elbein dos. O negro e a abolição: alguns subsídios para uma crítica da memória nacional. Petrópolis, Vozes 73 (73): 168, abr. 1979.

17. CARVALHO, José Jorge de. op. cit. p.35.

18. TAVARES, Julio César de Souza \& MORICONI, Sérgio Ismael Nunes. Zumbi: monumento à liberdade. Brasília, Cultura, out. dez. 1981. p.20.

19. NASCIMENTO, Milton; CASALDÁLIGA, Pedro; TIERRA, Pedro. Missa dos Quilombos. Ariola, 201.649, 1982. Stéreo.

20. Texto de Fernando Brant para o encarte de Missa dos Quilombos.

21. BOFF, Leonardo. $O$ rosto materno de Deus: ensaio interdisciplinar sobre o feminino e suas formas religiosas. Petrópolis, Vozes, 1979. p.176.

22. FINKIELKRAUT, Alain. A derrota do pensamento. Trad. Mônica Campos de Almeida. Rio de Janeiro: Paz e Terra, 1988. 


\section{REFERÊNCIAS BIBLIOGRÁFICAS}

1. AGUIAR, Carmen. Zezé Motta assume sua raça e resiste à discriminação. Presença da mulher, abr. jun. 1988. p. 18-20.

2. ALENCASTRO, Luiz Felipe de. O branco selvagem. São Paulo: Veja, 11 maio 1988. p. 34-43.

3. BERND, Zilá. Introdução à literatura negra. São Paulo: Brasiliense, 1988.

4. BOFF, Leonardo. $O$ rosto materno de Deus: ensaio interdisciplinar sobre o feminino e suas formas religiosas. Petrópolis: Vozes, 1979.

5. __ Os Sacramentos da Vida e a Vida dos Sacramentos: minima Sacramentalia. 4.ed. Petrópolis: Vozes, 1977.

6. BRANDÃO, Carlos Rodrigues. Os deuses do povo. São Paulo: Brasiliense, 1982,

7. CARNEIRO, Édison. Capoeira. Rio de Janeiro: MEC/FUNARTE, 1975. 23p. (Cadernos de folclore, 1)

8. CARVALHO, José Jorge de. Mestiçagem e segregação. Brasília: Humanidades, 1988. p. 35-9.

9. CASTRO, Marcos de. Dom Hélder. Rio de Janeiro: Graal, 1978.

10. CESAIRE, Aimé. Discurso sobre o colonialismo: presença africana. 1955.

11. DANTAS, Beatriz G. Taieira. Rio de Janeiro: MEC/FUNARTE, 1976. 30p. (Cadernos de folclore, 4)

12. DEISS, Lucien. A ceia do Senhor: eucaristia dos cristãos. Trad. João Pedro Mendes. São Paulo: Paulinas, 1977 (Crer e compreender)

13. FILHO, Adonias. O negro na ficção brasileira. Brasília, Cultura, out.dez. 1976. p.40-3.

14. FINKIELKRAUT, Alain. A derrota do pensamento. Trad. Mônica Campos de Almeida. Rio de Janeiro: Paz e Terra, 1988.

15. FREYRE, Gilberto. Aspectos da influência africana no Brasil. Brasília, Cultura, out. dez. 1976. p. 6-19.

16. _. Casa grande e senzala. 12.ed. Brasília: UnB, 1963 (Biblioteca básica brasileira, v.7)

17. HOLLANDA, Sérgio Buarque de. Negros e brancos. In: Cobra de vidro. São Paulo: Perspectiva, 1978. p.11-4 (Debates,

156)

18. HOOARNET, Eduardo. A igreja no Brasil-colônia (1550-1800). São Paulo: Brasiliense, 1982 (Tudo é história, 45)

19. JUCÁ, Cecília et al. Candeia/Quilombo. São Paulo, José, maio 1987. p. 2-12.

20. LEITE, Dante Moreira. O caráter nacional brasileiro. 3.ed. São Paulo: Pioneira, 1976.

21. LEITE, Paulo Moreira. Centenário de um mau século. São Paulo, Veja, 11 maio 1988. p. 20-33.

22. LÉVI-STRAUSS, Claude. Raça e História. In: Antropologia Estrutural. Paris: Plon, 1973.

23. LOPES, Helena Theodoro. A força vital. Brasília: Humanidades, 1988. p. 43-9.

24. MORGAN, Clyde Wesley. Danças e ritmos negros no Brasil. Brasília, Cultura, out. dez. 1976. p.20-9.

25. NASCIMENTO, Milton; CASALdÁligA, Pedro; TIERRA; Pedro. Missa dos Quilombos. Ariola, 201.649, 1982. Stéreo.

26. SANT'ANNA, Affonso Romano de. $O$ canibalismo erótico na sociedade escravocrata. Rio de Janeiro: Revista do Brasil, ano I no 1/84. p. 10-9.

27. SANTOS, Juana Elbérn dos. O negro e a abolição: alguns subsídios para uma crítica da memória nacional. Petrópolis, Vozes,

73 (73): 163-72, abr. 79.

28. SCHNITAZLER, Theodor. Missa: mensagem de vida. 2.ed. Trad. D. Matheus Rocha. São Paulo: Paulinas, 1980. (Sacramentos hoje)

29. SCHWARCZ, Lilia Moritz. Retrato em branco e negro: jornais, escravos e cidadãos em São Paulo no final do século XIX. São

Paulo: Companhia das Letras, 1987.

30. SILVA, Jacira. A casa da cultura negra. Brasília, Cultura, out.dez. 1981. p. 21-6.

31. SUSSEKIND, Flora. O negro como arlequim: teatro e discriminação. Rio de Janeiro: Achiamé, 1982.

32. TAVARES, Júlio Nunes. Zumbi: monumento à liberdade. Brasília, Cultura, out.dez. 1981. p. 18-20

33. TEODORO, Maria de Lourdes. Negritude e tigritude. Brasília, Humanidades, 1988. p. 27-30 